\title{
Exile and the Creative Imagination
}

\author{
Olu Oguibe, University of Connecticut
}

\section{Manchester, Connecticut, June 2004}

In the summer of 2003, the Migros Museum für Gegenwartkunst in Zurich staged a spectacular exhibition of works by African artists under the theme: The African Exile Museum. Included in the exhibition were works by Fernando Alvim, Oladele Bamgboye, Aime Ntaciyika and several other artists including this writer. Regardless of the museum's objectives, the project of an exile museum offered a most auspicious opportunity to revisit a theme that has been central to the African imagination and predicament over the past century.

It is the case that exile has marked the lives of many of the continent's most prominent creative individuals, from Wole Soyinka, Lewis Nkosi and Breyten Bretenbach who seem to have survived it, Dumile Feni, Arthur Nortje, and Alex la Guma who tragically succumbed to its unbearable grief, to Nuruddin Farah, Ibrahim El Salahi, and innumerable others who languish still in its infinite wilderness. The theme of exile has also been a fixture across the canon of modern African art and literature, from the fiction of Chinua Achebe and Ayi Kwei Armah to the drawings, paintings and installations of Obiora Udechukwu, Gerard Sekoto, Uzo Egonu, Kay Hassan and numerous others.

A comparison between Armah's and Achebe's fictionalization of exile is telling. In Armah's novel, Fragments (1974 [1970]), the brooding, unsociable hero is marked, then driven insane-he is literally chased through the streets till he breaches the symbolic perimeters of civility, whereby he is brought down, bound and delivered to a sanitarium. On the other hand, Okonkwo, the hero of Achebe’s Things Fall Apart (1958), is banished by his kinsmen for the reckless and near-fatal act of shooting at his wife in a fit of rage on 
a sacred day, an abomination believed capable of bringing the entire community to peril. For this he is sent into exile for seven years. Although in the popular imagination as well as in contemporary discourse exile almost always evokes a state of victimhood, the example of Achebe's hero reminds us that it needs not do so since excommunication and banishment could indeed serve positive purposes in regulating conduct and checking individual excess within the commune, or safeguarding the moral apparatuses that ensure the stability and cohesiveness of a world. Foucault does make this point in his work but by ostensibly recusing himself of all moral considerations, ironically places greater emphasis on the penal dimension of exile while holding the concept of communal survival suspect, whereas Achebe points to its validity by contextualizing Okonkwo's predicament. That said, the psychological burden of exile is the same irrespective of the circumstances of exit, and no form of exile is less painful, injurious, or frustrating than the other.

In an itinerant, cosmopolitan age in which movement and relocation are as ubiquitous as they are inevitable, it would seem as though the fixation with home, place and geography with which the exile is preoccupied, is a primitive affliction from the distant past, a residue from a long forgotten, sedentary epoch when humans ventured no farther than the boundaries of clan and nation. But there lies the irony of the exile condition, for exile is not so much about movement, relocation or departure as it is about loss: loss of the freedom to remain or return to things familiar. Exile is a rupture, the cessation of things previously taken for granted, the collapse of a world of relative certainties, and therein lies its sting.

In 'A Song for Occupations' (originally published in 1855), Walt Whitman celebrated the elemental desires and conditions that sustain the spirit in an itinerant age, including the will to depart but even more importantly, the liberty to return. 'Will you seek afar off?' Whitman asks of his wayfaring protagonist;

... you surely come back at last. In things best known to you finding the best, or as good as best, In folks nearest to you finding the sweetest, strongest, lovingest, Happiness, knowledge, not in another place but this place; not for another hour but this hour. $(1950,175)$

Our age may be marked by unprecedented freedom to depart from home, to sojourn, and 
to venture even to the farthest reaches of the universe; yet what emboldens us to leave and venture is the knowledge that no matter when or how we depart, or how long or far we journey, we may readily return, of our own free will, to all that is familiar to us: the scents, smells, liberties and safeties that we call home. What gives exile its peculiar poignancy, then, is not so much the essential act of departure, as the nature and condition of that departure. The sojourn of exile is particularly tragic because it is inevitably, inescapably bracketed by the fact of loss, not of things willingly forsaken but of things forcibly left behind, things from which separation is a violent act that leaves a wound for which there is no healing, even to the grave. Even in the bravest and most optimistic of circumstances, exile is also marked from the beginning by the fact that the exile leaves or flees certain only that they may never return. Exile, therefore, is the very antithesis of the cosmopolitan spirit, for where one is marked by the freedom to roam and return, the other is defined by an essential conditionality in the form of denial of the liberty to remain or return, and forcible severance from all that is dear and familiar.

Exile demands contemplation because it is unavoidably real for those who experience it. More than a word, exile is also a condition. It is a place, a knowledge, a narrative, but most importantly, it is a psychic space that is obvious to those who inhabit it, those who must engage and wrestle with it because only by so doing can they come to terms with it. It is often observed that exile is a fertile ground for the creative imagination, but this is so not because it offers a choice but precisely because it does not. Every engagement with the lived experience of exile finds its most persuasive explanation not in fascination, for there is no such thing as fascination for exile, but rather in the individual quest to come to terms with the fact of exile. Every such effort is an attempt to explain exile more to oneself than others, to shore up against one's ruins. Engaging with exile is a technology of the self. 


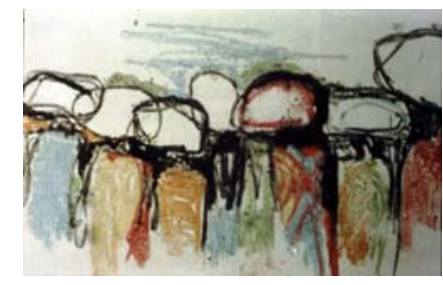

Figure 1: Oso Ndu [Flight], 1984

For as long as I recall, exile has recurred in my work as an artist and thinker, beginning with the very earliest art that I made as a child, a line drawing of an endless train drawn in the sand on the grounds of my father's parsonage in 1968, at the height of the Biafra war. My family and I thrice fled from that war as refugees. The theme of exile recurs, again around the image of the train, in 'The Exile Train', a drawing from my late teens, and in 'Oso Ndu' (Flight), a monotype from the same period, both of which were informed by my experience of flight as a child in Biafra (See figure 1). We may even infer the same theme in yet another drawing from that period, a pastel erroneously titled 'The Louisiana Seventeen', which drew its subject matter from the myth of Ibo Landing. A central motif of lore in the U.S. South, Ibo Landing recalls an incident from the era of slavery when a group of Igbo men and women, having been abducted and sold to slavers in West Africa, and having survived the long and horrific journey on the Middle Passage to the Americas, alighted on the coast of the Carolinas. But rather than proceed into slavery, they turned back and walked into the sea, whereby they drowned together, holding hands and singing. The condition of their departure, and the horrors of the Middle Passage, had foretold the future of their exile. Rather than live that prospect, those distant kinsmen of mine chose instead to die, but not without the supreme symbolism of doing so while facing homewards, dying in the course of a futile return. They would not be buried in a strange land.

In my work the theme of exile makes its most impassioned appearance, perhaps, in the self-evidently titled poem, A Song from Exile (1990), written shortly after my arrival in England in 1989. On the face of it, I had traveled to England to study, but the bitter truth was that my journey was no less than a painful, deeply conflicted and reluctant flight from persecution at home. In the long poem published in London and Bayreuth in 1990, the protagonist equates his departure with the loss of voice and tongue, and quite contrary to the convention which associates exile with creative fertility, implies that exile instead is a journey from fertility to aridity, a journey of irreparable loss. 'I have journeyed away 
from the sea into the desert', the poet-protagonist states in the first stanza of the poem, 'The songster has journeyed without his voice.' Though the poem is consumed by the nostalgia that plagues both expatriate and exile alike, the same nostalgia that we find in Sekoto’s paintings recalling South African townships or Uzo Egonu’s paintings recalling a beatific childhood in Nigeria, it is nevertheless underpinned by that deeper sense of loss and inconsolable anguish that distinguishes expatriation from exile and sometimes manifests in an acutely romantic phantasie of home. In this instance, such phantansie seems paradoxical since the protagonist's dilemma is predicated precisely on the condition that home had proved inhospitable. Why would one fantasize about an inhospitable home from which they have fled into exile? To resolve the paradox, the poem pitches home against the place of exile, and paints a picture of the latter as equally inhospitable, if not more so. By repeatedly employing the metaphor of the abused mother, the poem carefully implies that, far from being inherently inhospitable, the home from which the protagonist fled is as much a victim as the protagonist. The poet fled home not because home was inhospitable, but because it was under the rule of what Christopher Okigbo described as 'the pot-bellied watchers [that] despoil her' (1971, 50). This being the case, exile may offer refuge but not solace or a sense of pride.

So strong is the protagonist's sense of alienation in exile that the fourth movement of another poem of mine from the period, 'For You, Homeland' $(1992,78)$ manifests the same sentiment that drove the heroes of Ibo Landing to drown in the sea, namely the determination not to be buried in exile. In the second stanza of the movement, the poetprotagonist states:

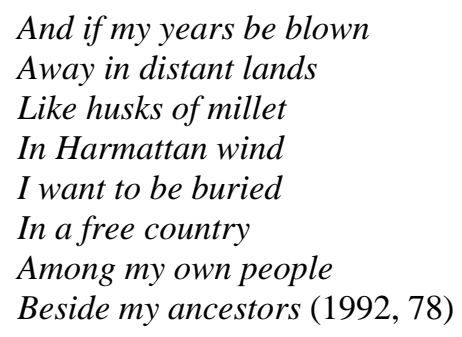

These sentiments were echoed in several drawings and paintings that I made in the late 1980s and early 1990s. In a watercolor from 1990 titled 'Exiles' there are two figures, a couple. One of them has lines hatched across the forehead that represent facial scarification, in particular those found on Igbo men of distinction. The figure with the 
scarification has a blank stare; his companion is downcast. Caught in the blank landscape of exile where all things must start anew, the painting appears to suggest, the past becomes mere memory for the couple, and because this memory is all that the exile is left with, it is so dear that the thought of its loss strikes terror in the heart.

In the iconography of the painting the most important motif, perhaps, is also the least obvious, which is the scarification on the exile's brow. In the old Igbo society, an individual so distinguished as to earn the scarification on the brow could never be subject to the humiliation of exile unless he committed the very worst abomination. However, with the advent of a new dispensation, the world that created and sustained that condition fell apart and even the sacred was made profane, making it possible to contemplate a fate as unthinkable as the exile of an Igbo noble. The humiliation of colonialism was most poignantly inscribed in the banishment of men of status and distinction, like Jaja of Opobo, who was banished to the Caribbean by the British, or the Edo monarch Oba Overamwen, who was banished to Calabar after the sack of his kingdom. These were pillars of society who by their very status and integrity represented the order of things that colonialism violated and ultimately destroyed. As would become evident, postcolonialism did not restore that order, but instead created new machineries of debasement and ruin, the results of which include the involuntary exile of citizens, noblemen and commoners alike, now scattered around the world in a new, infinite Diaspora. The motif of the scarified noble in exile symbolizes this unraveling while reflecting the anxiety and grief that arise from the terrifying knowledge that time wounds all heels.

Another watercolor titled 'The Poet and His Mother' (See figure 2) addresses the subject more cryptically using the same metaphors that occur in A Song from Exile, with home or the homeland as the mother, and the exile as the poet. The image of the mother and child was already a leitmotif in my work, beginning with the teenage drawings and paintings mentioned earlier, and was inspired not by the convention of the Madonna, but by the equally biblical theme of the only son whose mother was a widow, as narrated in the seventh chapter of Luke's Gospel. In my earlier work including paintings from the middle and late 1980s, the image of the orphan and his widowed mother as well as the figure of the absent father addressed the agonies of war, specifically the Biafra war in which so many of my generation were orphaned. It also implied a special bond between mother and son, a bond that derives from the demands and inevitable truth of common loss. In 'The 
Poet and His Mother,' as in my A Song from Exile (1990), the image is employed to symbolize the parallel bond between the patriot poet and his homeland. In the watercolor, the prospect or fact of the poet's separation from his mother represents the acute grief and loneliness of exile in same way that the image of the only son and his widowed mother represented the insufferable tragedy of war and loss in my earlier work. Unspeakable grief was the recurrent theme.

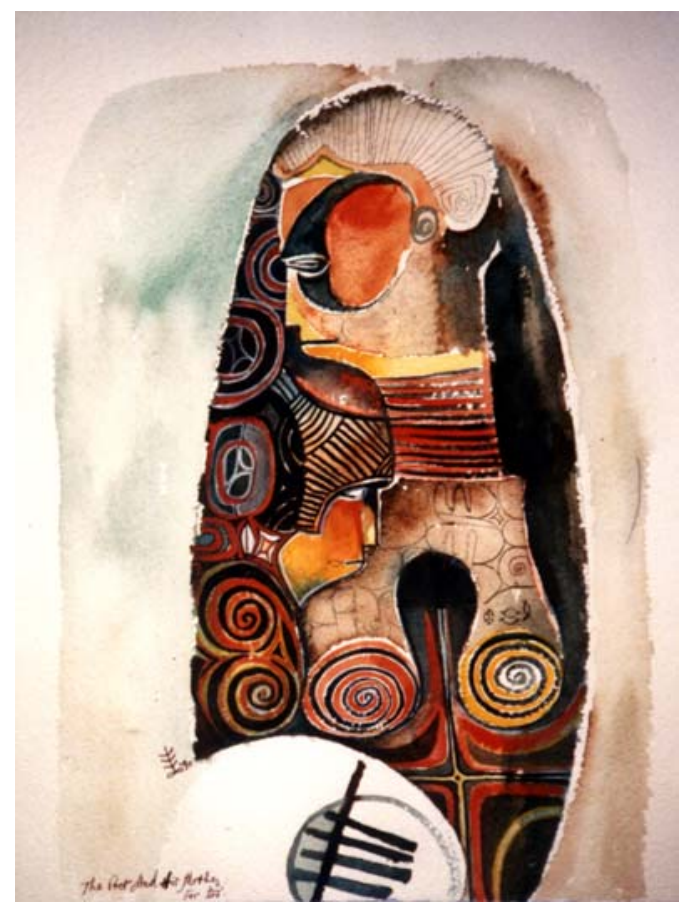

Figure 2: The Poet and His Mother, 1990

A few years after A Song from Exile was published, I wrote a brief essay called 'Imaginary Homes, Imagined Loyalties: A Brief Reflection on the Uncertainty of Geographies' (1996), which dealt with the problematic, twin notions of home and homeland. As if weaning itself from the purple nostalgia and consummate grief of the poem, the essay seemed instead to celebrate the cosmopolitan utopia of freedom from the burden of belonging, which these notions contradict and often compromise. The essay proposed a concise history of the idea of home, and traced it to a natal absence and longing, an almost biological yearning which derives from the trauma of separation from the womb and ultimately manifests in a proprietary claim to a familiar geography where such claim may meet the least possibility of contestation. Home and homeland, it insisted, are mere projections with little anchor in physical or indeed reciprocal, emotional reality, 
fictions whose purpose is to satiate a perennial longing for the womb as well as the human instinct to name and possess.

Because the object of claim, that is, the place called home, does not reciprocate the claim made on it or return the affection projected on it, it was my conclusion that such affection is essentially narcissistic and delusional, and the bond on which it is assumed to rest merely fictional, just as it is treacherous. And, since the larger notion of homelands and the purported rights that accrue from that notion build upon this fiction of a bond between individual and natal geography, it was my conclusion that the idea of homelands is also delusional if ingenious, and those who latch onto and swear by it are often repaid with betrayal.

The fiction of home and homeland, the essay further proposed, reveals itself in the decoupling act of expatriation, after which we discover especially upon return and often to our surprise, even heartbreak, that the bond between the individual and the homeland is tenuous. Not only do we find that the homeland is inherently indifferent; sometimes we discover, also, that it is capable of treating us no better than the geographies of exile. The more we travel, the more we learn, and should we return after having departed home, we often realize that home and homeland, the objects of our patriotic projections, care little for us or our loyalty. The idea, then, that we belong to a place, and that that place in turn belongs to us, merely exposes us to disappointment, and conditions us to contest for and die over a fiction, which, by its very nature, denies and defies belonging.

Like all theories and propositions, the essay in question had its limitations and obviously placed several valid considerations outside its sphere of concern. More importantly, although it revolved around the will to escape, to detach oneself or self-excommunicate, or simply to celebrate the absence of geographical or natal anchorage, it was nevertheless still part of my long, perennial wrestle with the predicament of exile in what one might call its third phase. Whereas the teenage drawings referred to earlier emerged from residual grief over the refugee experience in Biafra, and the paintings and poetry from my years in England drew from the grief of exile, this essay, written in the very first months of my relocation to America, seemed to resolve the emotional and existential complexities of what one might call the Odyssey on the exile train by contesting the logic of attachment to home and homeland without which, indeed, there is no exile. 
There was another context or background to the essay and its attempt at what we might call the logic of renouncement. In the mid-1990s when the essay was written, there was a resurgent, euphoric discourse around what was at best a revived utopia, namely the birth of a new territory of cosmopolitan freedoms called the Interzone, a territory beyond the constraints of nation and faith, a borderless zone of unimaginable possibilities. Fuelled by the advent of new information technology, especially the Internet, as well as certain streams of cultural studies that sought to posit clarity and identity as irresoluble by introducing notions such as hybridity, discourse at the time ignored the realities of geography and its politics and adopted escapism by envisioning an imminent, new 'postnational' world where technology erased all boundaries and extant truths, and granted infinite connectivity and unbreachable community to all world citizens. This new, postnational world, the latest in a long line of 'post-' conditions, with its universal brotherhood of the dislocated and its grand technological advancements, channels of navigation, and re-negotiated relationships, would supersede the archaic structures and inefficiencies of all prior forms of belonging. The new age would be one without regulation, an age of triumphal cosmopolitanism. Scholars and pundits such as Homi Bhabha (1994) and Nicholas Negroponte (1996) mesmerized the intellectual community with visions of this hybrid, borderless post-humanism which, as Bhabha seemed to argue, represented the inherent nature of postcoloniality.

The period was one, also, of seemingly unprecedented cosmopolitan prominence for intellectuals from the provinces: Francis Fukuyama published The End of History and the Last Man (1992), Bhabha followed Nation and Narration (1990) with The Location of Culture (1994) and the ultra-conservative Dinesh D'Souza $(1993,1995)$ achieved shortlived celebrity in America with a series of polemical propositions. The rhetoric of a borderless post-histoire was on the ascendant.

The appeal of this borderless vision was strong and understandable. Anyone for whom every border-crossing is a march through Golgotha, a ritual of persecution, a crucifixion in which the body is laid bare and the soul abused, would understand the appeal of its promise: more so those who were already loose of anchor and thus carried their nation in their suitcase. Hence the enthusiasm with which many began to embrace the notion that the nation is a fiction, and worse still, a disposable one. 
However, it was not long before one was reminded that the 'world city' or cosmopolis at the center of this vision is not the imagined, lawless wilderness of the Interzone: that the cosmopolis, after all, is an owned territory.

The cosmopolis derives its name from kosmos, the cosmos, but at no time in the past and hardly so now, was the cosmos ever understood to represent any more than the 'known world', that is, the world as known and determined by the culture that defines it. Each society and culture constitutes its own world, in its own way and according to the perimeters of its knowledge and the dictates of its interests. There is therefore no single world or cosmos but many, and every cosmos is the material and spiritual property of the culture that creates or defines it. Every world is owned.

Needless to say, the mere fact of presence or habitation does not grant access to a world because a world transcends physical geography. A world is more than a place or polity or constellation of dominions. Each world is a territory in the mind, also, and the borders of the mind are more intractable than borders on a map.

To have access to a world requires belonging, and habitation in a world, by itself, does not equal belonging unless the subject is in his or her natural surroundings, for, it is one thing to inhabit a place and quite another to be in one's place. So that mere physical presence, or even the mental projection of belonging - the wishful assumption of belonging - does not in real terms translate into being part of a place; to be in a place is not the same as to be of that place.

And if the foregoing appears rigid and problematic, especially against the background of the utopia described above, or indeed the propositions of my earlier essay on imaginary geographies, perhaps the reader ought to be reminded that this perspective is not peculiar to those who are often seen to have come from the so-called peripheries of the world, but is in fact a shared truth among most who journey outside their homeland irrespective of their provenance. In other words, skepticism towards the utopia of the borderless postnation is not a postcolonial or subaltern affliction. 
Pablo Picasso spent almost all his adult life in Paris, one of the great 'world cities' of the nineteenth and twentieth centuries. He was, to all intents and purposes, Parisien par excellence and hardly anyone in his time could be considered more so. However, it is also known that on several occasions Picasso applied to the authorities to become a French citizen, not in order to deny his Spanish origins but so as to consolidate his sense of belonging in Paris, of belonging to it. However, that wish was never granted till his death. Later in his life, thanks to the repeated rejection, Picasso's nationalistic feelings towards Spain hardened into defiance and he was known to declare with marked vehemence that he was a Spaniard and would remain so till death. After numerous years living in Paris and, indeed, helping to define that city for his age, Picasso's efforts to obtain French citizenship derived from a profound knowledge of what it takes to claim a city and a place, an understanding that without being French he could not truly claim Paris. For, while the two might appear autonomous, in truth they are bound together like mother and child; there is no Paris without France, and the world for which Paris is a world city is a French world no matter who inhabits the city or that world, or where they come from. Picasso did not belong in the French world.

Having lived in Paris as long as he did, Picasso understood that in every world city, every cosmopolis, there are two categories of inhabitants, two categories of cosmopolitans. There are those who walk with the steady gait of belonging, their feet solidly planted in the knowledge that they not only inhabit the city but own it as well as the world that defines it. And then there are those who walk with the mechanical uncertainty of all who pitch their tents on the sandy, tidal beaches of rented habitats. The people in the latter category may inhabit the world for which the city is a center but they do not define or own that world and as such. Whether they choose to acknowledge it or not, they live permanently on borrowed time and the succor and restfulness of home is eternally denied them. They may call the city home, but deep within them they know that home must feel different, no matter how vague and inchoate, even unsavory, it seems. This knowledge I have carried all my life.

Little surprise, then, that the theme of exile and belonging should reemerge in my work at the turn of the century, this time in the installation, 'Game' (see figure 3) which was made in the summer and early autumn of 2002 in the studio of master ceramicists Anna Maria Pacetti and Ernesto Canepa in the little, seaside resort town of Albisola Marina on 
the Italian Riviera. The elaborate ceramic piece, comprising a mural and a group of terracotta figurines, was exhibited the following year in the old atelier of the late Lucio Fontana across the bridge in the twin town of Albisola Majore, the first work by another artist to be shown in the late master's studio. Fontana, whose revered atelier had passed into the custody of the municipality, was a native son once removed who left his birthplace in Argentina to return to live, and die, in Italy, his ancestral home and the land of his forebears. It was in this atelier that Fontana created his famous slashed canvases.

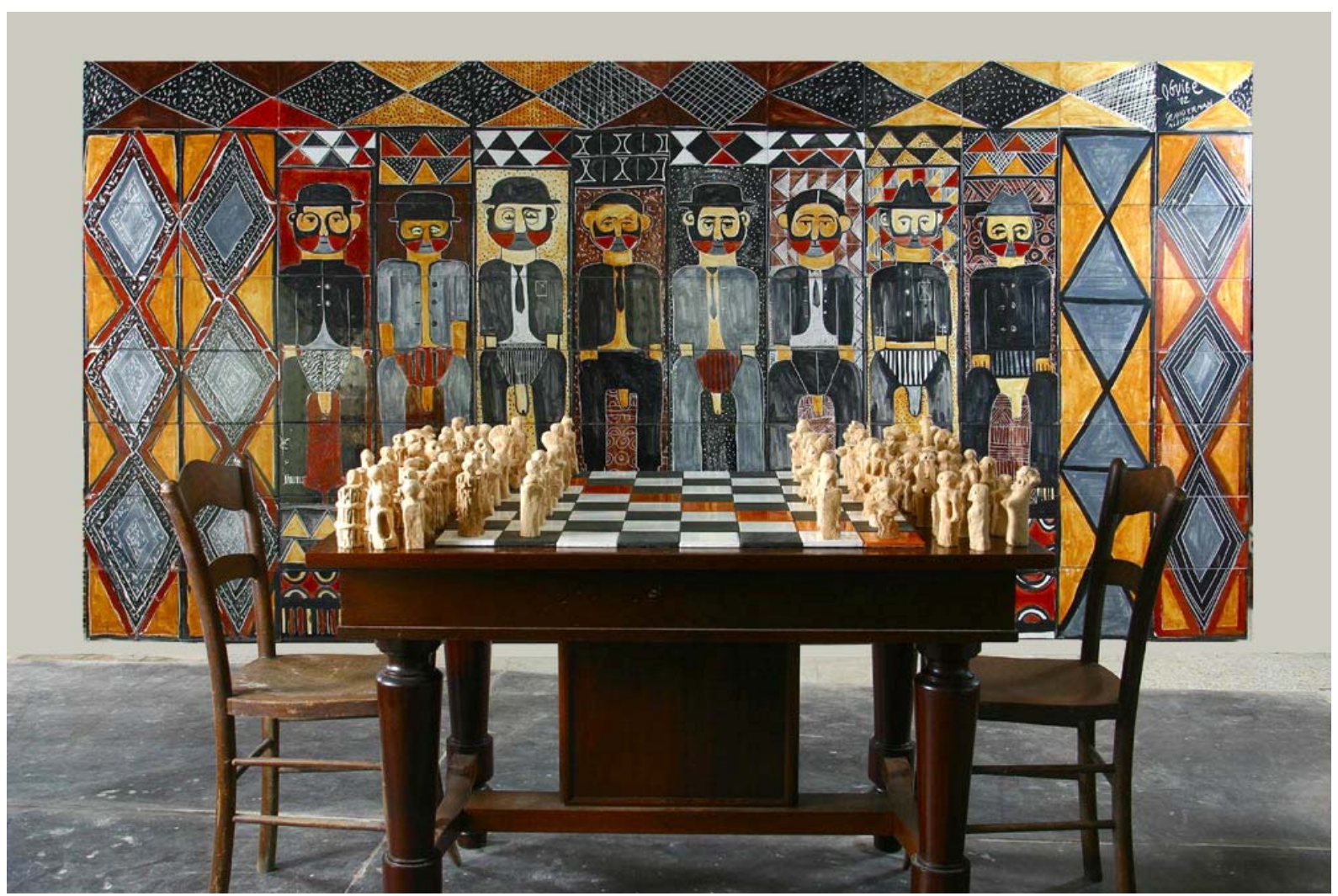

Figure 3: Game, 2002-2003

In certain respects, 'Game' began its life in a third-floor, Brownstone apartment in Brooklyn, New York where it was conceived a few weeks before I set out for Italy. When I arrived in Albisola to produce it, only the barest details were certain: that the work would comprise a tiled mural of a certain dimension, the image for which was as yet to be determined, as well as a group of statuettes or figurines, the number and specifics of which would equally be determined in the course of their making. Each figure on the four-meter mural was conceived in the process of its painting. So were the hundred and one figurines, some of them loosely based on iconic sculptures from different West and Central African cultures. The name of the work too would change. At first it was titled 
'Strangers and Gods', with reference to a suspect yet enthralling image in a favorite line at the end of T. S. Eliot's 1927 poem, 'Journey of the Magi’:

We returned to our places, these Kingdoms,

But no longer at ease here, in the old dispensation,

With an alien people clutching their gods. $(1969,104)$

Though Eliot's lines refer to an ancient aristocracy on the eave of an upheaval, nevertheless, since my arrival in the West, his image of an alien people clutching their gods has always represented for me the stream of migrants and strangers that I come across in city after city and equally evoked in my A Song from Exile (1990). These masses have come from all corners of the world, from the nearest and farthest border posts of Empire, to seek refuge and revenge in the imperial cosmopolis. They are travelers and exiles, prospectors in the dry and coarse mines of the center, claimants to a vague yet barely forgotten right to the riches once taken from their homelands and funneled to the West, upon which the paved streets of Empire were built, each man, woman and child bringing with them a speck of dust from whence they came, a pouch filled with the earth on which they or their ancestors once walked only to leave behind, perhaps forever. Aliens clutching their gods; strangers, of whom I am one.

It was my intention that the figurines in the work (see Figure 4) should represent these multitudes and their gods, the number hundred and one representing as it does in my other works an infinite mass of peoples of all nations, faiths and tongues, a legion. And, though the figurines or statuettes would formally be modeled on vague recollections of god-images and effigies, the gods in the work would be represented not by the statuettes but by a number of life-size male figures in the mural who shall tower over the statuettes like distant yet ever-present lords and masters. The roles would be reversed and the strangers would be the gods and the god-images would be the strangers.

However, there is another version to the narrative that begins in Albisola itself, for although the form of the work that I made there took shape in New York, some of the thoughts and emotions that inspired it began two years earlier in the same Italian town while I was a guest there. It was the summer of 2001, and the leaders of the Group of Eight industrialized nations were meeting in Genoa, a score miles away from Albisola. 


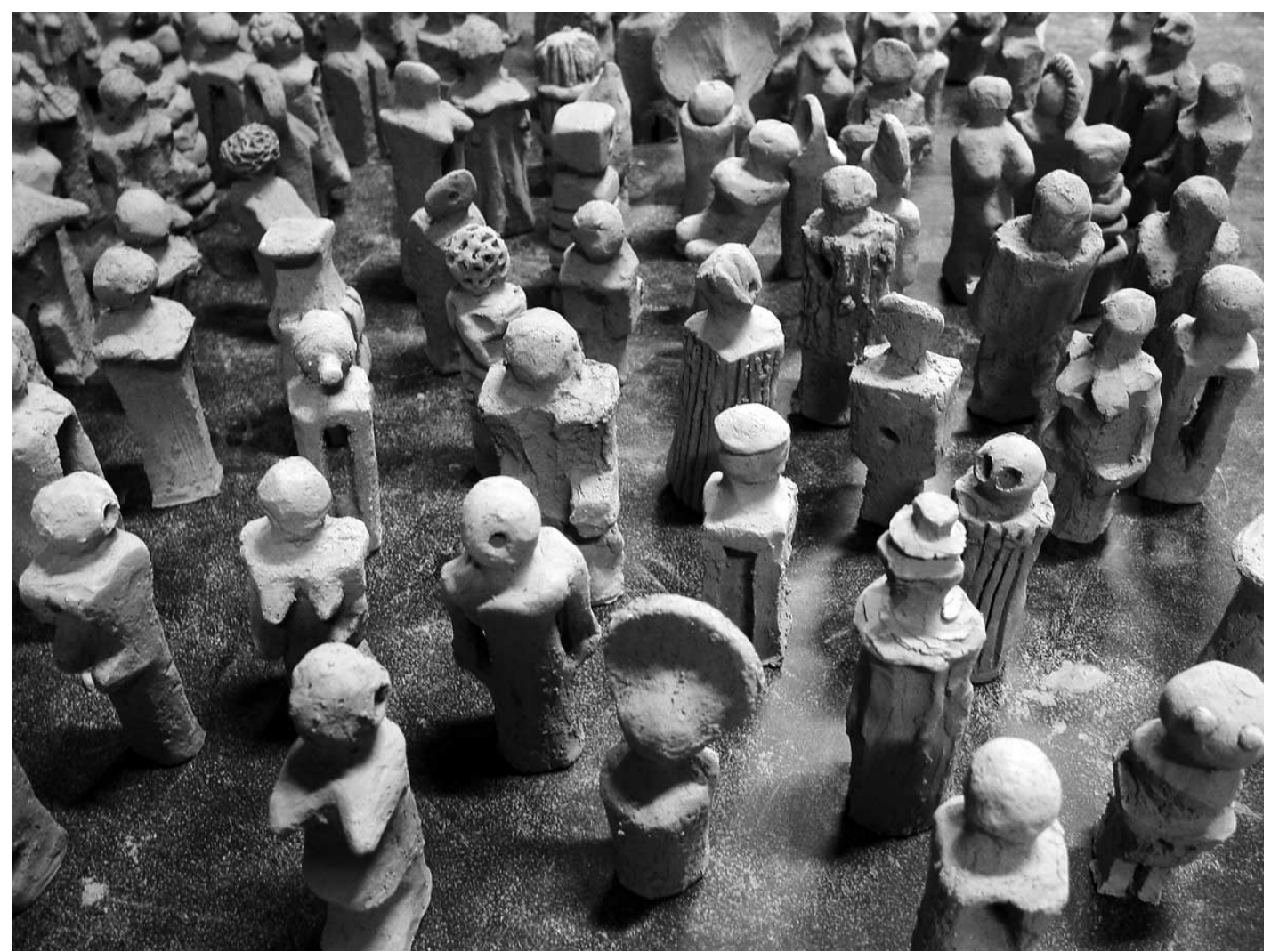

Figure 4: Pieces for Game, 2002-2003.

The region was aswarm with security personnel and there was tension in the air that uneasily recalled an unnamable period in Italy’s not so distant past. Before long, running confrontation between the security forces guarding the meeting and masses of protesters who came to voice opposition to the visiting leaders and their global policies turned into tragedy. A young protester by the name of Carlo Giuliani was slain by police, making him the first open martyr of the emergent battle against triumphant capital in the new millennium.

The slaying in Genoa remained on my mind for the next two years, as did the issues that led to the young man's martyrdom. And as I prepared to work on the installation in Albisola the image resurfaced of a group of strong men who regulate and oversee the fate of the world's weak and dispossessed, from factory workers to refugees, from immigrant tomato pickers and indentured laborers in citrus orchards to coal miners, men at whose behest the weak would be murdered in the streets and citrus orchards and factory floors. The latter - the immigrants and refugees and office cleaners and factory hands of the world, the loose populace of the globe, Fanon's wretched of the earth—would be the 
strangers in my work, while the former, the men of power, wealth and strength, would be the deities, the modern day gods.

As significant as the event in Genoa was for me, then, so was a longer and much deeper preoccupation with the larger question of the fate of the rootless among these masses, these alien people in the centers of the West or wherever they may be, for whom home is at best a far away place and, at worst, a mere notion in the mind. These are the refugees and exiles and expatriates of the world who are condemned to dream of homelands, and in whose faces I see my own. I dwell on their fate in order to understand mine.

At the turn of the century, as wars of colonial occupation rage on the one hand, and nationalist struggles drag out on the other, and the industrialized nations continue to seal their borders against invading aliens clutching their gods, the soporific discourse of postnationality and Interzones has dissipated, as it should, because the experience and fact of unbelonging upon which it was largely built does not, in and of itself, realize or substantiate the utopia of the post-nation. In time we have come to acknowledge that the only free movement across territories that the present allows is the trespass of the powerful against the weak.

The triumph of global capital, or so-called globalization, has failed to quell the march of powerful nations to seize and possess territory. Paradoxically, globalization has produced its own dislocated and dispossessed by destroying the economic and cultural fabric of hapless societies from Gujarat in India to Chiapas in Mexico, and fuelling strife around the globe, from the Persian Gulf to the Congo. Individuals as well as whole populations continue to flee persecution, deprivation, cataclysm and war, and the global refugee train continues to swell. For most who suffer these calamities, the question of home is particularly acute because it codifies the very barest essence of their humanity in a cruel and restless world. Those who take the privilege of a safe home and a protective homeland for granted cannot imagine the trepidation and loneliness that is the fate of strangers. It is a terrible thing to be alone in the world, and those who have no place to call home are the loneliest of the lonely. To suffer the loss of home and homeland is to be truly dispossessed. 
Exile persists, and its persistence speaks to the resilience and relevance of geography. It also underlines the inescapable desirability of belonging. It may be questioned, even ridiculed, but only those who have experienced the loss of home can understand the rootlessness — and ruthlessness_ — of existence in the shiftless, treacherous territory of exile.

How, then, does one cope with the fact of exile?

The persistence of exile explains its recurrence in the work of artists and writers, not only in Africa but around the world, whose fate it is to deal with the predicament. The preoccupation with exile recurs in my work and those of others because art provides us with a handle on the fact and memory of dislocation and unbelonging; a safe space to dream and contemplate, even mourn.

As noted earlier, exile is poignant because it is bracketed by loss — of territory, of the familiar and the familial, of certainty_-but most frighteningly, by the grave probability of the loss of memory. Exile is also an in-between place where nothing is firm. In exile no project is possible except as either reflection or proposition, as prolegomena, at once underlined by the sensitive and fragile memory of loss and beset by the anxieties and uncertainties of dreaming in a place without guarantees. This is why exile may only be lived down fruitfully in that embattled yet mobile and secure territory called the Republic of the Imagination. In exile every act is an act of faith, and only projects of the imagination may exist in the present tense.

Art, and faith, therefore, are the only possibilities open to the exile because they transcend the strictures of the existential. Like little safe havens, art and faith provide a space from whence dream and determination may battle the myriad traumas of survival away from home. Through art the exile is able to escape the burden of circumstance, even the temptation of bitterness and recrimination, and thus question, explore, ruminate, and attempt to repossess fragments of that which is lost. The creative imagination allows the artist to repossess and re-inhabit home while away, and live its anguishes and truths, like Nuruddin Farah has done through his novels and Dumile Feni and Ibrahim El Salahi did through their drawings, like Pablo Picasso through 'Guernica'. Through art the exile may 
return, in a manner of speaking, by reconstituting the past, participating in the present, as well as envisioning a new world.

In dealing with exile, art and poetry have served me as spaces in which to reminisce, contemplate, fantasize, and ultimately transcend the exile’s habit of pain.

\section{Reference List}

Achebe, C. 1958, Things Fall Apart, William Heinemann, London. Armah, A. K. 1974 [1970], Fragments, William Heinemann, London.

Eliot, T. S., 1969, 'Journey of the Magi,' in The Complete Poems and Plays of T.S. Eliot, Faber and Faber, London and Boston, 103-4.

Fukuyama, F. 1992, The End of History and the Last Man, Free Press, New York. Bhabha, H. (ed.) 1990, Nation and Narration, Routledge, London and New York. Bhabha, H. 1994, The Location of Culture, Routledge, London and New York.

D’Souza, D. 1993, Illiberal Education: The Politics of Race and Sex on Campus, Vintage, New York.

D’Souza, D. 1995, The End of Racism, Free Press, New York.

Negroponte, N. 1996, Being Digital, Vintage, New York.

Oguibe, O. 1990, A Song from Exile, Bumerang-Verlag Norbert Aas, Bayreuth.

Oguibe, O. 1992, 'For You, Homeland,' in A Gathering Fear, $2^{\text {nd }}$ ed. Kraft Books, Ibadan.

Oguibe, O 1996, 'Imaginary Homes, Imagined Loyalties: A Brief Reflection on the Uncertainty of Geographies' in Interzones: A Work in Progresseds. O. Zaya and A. Michelsen, Tabapress, Copenhagen.

Okigbo, C. 1971, Labyrinths, William Heinemann, London.

Whitman, W. 1950, 'A Song for Occupations,' in Leaves of Grass and Selected Prose, Modern Library, New York. 